\title{
Employees' Defining and Driving Work Engagement in the University of Bohol
}

\author{
FRANCES MAE C. TRABAJO \\ ORCID No: 0000-0001-8471-9730 \\ rheeka_trabajo@universityofbohol.edu.ph
}

\begin{abstract}
Employee engagement in this study is all about employees finding meaning in their work, and commitment to support organizational goals. This spurred the conduct of this study which assesses the profile of the tenured employees of the University of Bohol and their level of engagement in terms of defining and driving engagement. This study is using descriptive normative method that employed quantitative and qualitative method and data analysis and interpretation using frequencies, percentages and weighted mean. On defining their work engagement, employees strongly agree or were highly engaged/ committed in their work and on drivers of engagement they agree or were motivated/driven in their work. Although the study yielded positive results as to defining and driving work engagement on the perception of the tenured nonteaching employees of the institution, there is a need to look into ways to sustain employees' engagement for the success of its organizational goals.
\end{abstract}

\section{KEYWORDS}

Employee Engagement, Organizational Goals, Descriptive-Normative Method, Tagbilaran City, Philippines 


\section{INTRODUCTION}

Employee engagement is a construct that is receiving increasing attention. It implies an employee's attachment and commitment to work roles. Engaged employees find meaning in their jobs and value the workplace as more than just a place to earn a living. They feel a sense of belongingness or identity to the institution - commitment, involvement and service are enthusiastically offered to achieve institutional success. Markos (2010) views engagement as more than the concepts of job satisfaction, employee commitment and institutional citizenship behaviour. It is a mutual and dynamic relationship shaped between employer and employee.

The level of work engagement in this study focuses on two dimensions: 1. defining engagement and 2. driving engagement. Defining engagement encompasses the perceived attributes that measure an employee's sense of pride, worth and belongingness to the institution. Driving engagement refers to the perceived attributes that measure an employee's relationship and interaction with peers, customers, superiors and institution. These attributes also include the perceived driving force of the workplace in terms of compensation, benefits, recognition and other rewarding resources provided by the institution.

The theory of Herzberg and Blau can help determine the level of work engagement of employees. Frederick Herzberg postulated that two classes of motivation to work exist, namely, the extrinsic and intrinsic. The intrinsic factors are viewed as being derived from the individual's relation to the job itself. Extrinsic factors are sources of motivation or need satisfaction. The outcome of work, either it is a success or a failure is highly determined by the attitude of an individual in relation to his work. The source of motivation as extrinsic/ hygiene factors, to mention, salary, work conditions, and job security would eventually provide satisfaction among the employees. Motivation factors such as recognition, responsibility, growth, and achievement result in better job performance (Robbins and Judge 2011).

Blau (1964) suggested the norm of reciprocity that has been utilized to explain the relationship of perceived organizational support and the interchange of leader-member with employee attitudes and behavior (Wayne 1997). Trust is the basic stronghold that allows the exchange of goodwill in future dealings. The specific benefits exchange may be valued primarily because they are symbols of a high-quality relationship; it is the exchange of mutual support that is of concern to the parties involved (Settoon et al, 1996). 
Several studies had been conducted regarding employee engagement; a study by Miller (2008) reveals that high level of engagement accelerates organizational performance observed through customer loyalty and retention of talent. Another study found that increase productivity and higher profits are associated with high levels of employee's engagement (Robbins and Judge, 2011). Likewise Whites (2013) concluded that high level of engagement is highly related to a manager who directly ensures opportunities for growth and development, space to innovate, respect and recognizes the contributions of his subordinates.

The non-teaching employees of the University of Bohol were the participants of this study; they were chosen because they too play a very important role in institutional productivity and success. The findings of this study will support the human resource development program of the institution to sustain employees' engagement and retention. The study feedback can serve as basis to implement change and formulate strategies that would improve work performance thereby increase the overall effectiveness and productivity of the institution.

The study looks into the profile of the employees, the perceived level of engagement of employees in terms of defining engagement and drivers of engagement.

\section{METHODOLOGY}

The respondents were the sixty-three non-teaching tenured employees of the University of Bohol. Descriptive normative survey method was employed with the aid of a research instrument as data gathering tool.

The research instrument explores the following: Part 1 contains information on the profile of the employees, Part II on defining engagement and Part III on driving engagement. The Likert style of item construction was adapted to identify the perceived level of employee's engagement in terms of: a. defining engagement; and $b$. driving engagement. The constructed items were modeled from the studies of the Global Workforce by consultancy Towers Perrin.

Statistical formulas were used to determine the percentages, weighted mean and composite mean to support the analysis and interpretation of data. Below are the prescribe weight equivalent, description, meaning and arbitrary scales used in the analysis and interpretation of data: 


\begin{tabular}{|l|l|l|l|}
\hline $\begin{array}{l}\text { Weight } \\
\text { equivalent }\end{array}$ & Description & Meaning & Arbitrary scale \\
\hline 4 & Strongly Agree & Highly engaged/highly driven & $4.0-3.25$ \\
\hline 3 & Agree & Engaged/driven & $3.24-2.50$ \\
\hline 2 & Disagree & Least engaged/least driven & $2.49-1.75$ \\
\hline 1 & Strongly Disagree & Not engaged/not driven & $1.74-1.00$ \\
\hline
\end{tabular}

Focused group discussion was conducted to deepen understanding of the information gathered from the research tool, thus, facilitate free willing discussion to express concerns and issues pertaining to the workplace environment.

\section{RESULTS AND DISCUSSION}

\section{Profile of Participants}

Majority of the participants were 41 years old and above (71.43\%), followed by 31-35 years old (12.70\%), 36-40 years old $(9.52 \%)$ and $26-30$ years old (3.17\%). Most of the non-teaching tenured employees were females $(57.14 \%)$ and only $42.86 \%$ were males. Majority of the participants were married $(77.78 \%)$; the rest were single (19.05\%) and widower (3.17\%). Majority have rendered their services for 21 years and above (38.10\%); $22.22 \%$ for $16-20$ years; $19.05 \%$ for $6-10$ years; $11.11 \%$ for $11-15$ years and $9.52 \%$ for $1-5$ years.

Table 1. On Defining the Level of Engagement $\mathrm{N}=63$

\begin{tabular}{|c|c|c|c|c|c|c|c|c|c|c|}
\hline \multirow{2}{*}{ DEFINING ENGAGEMENT } & \multicolumn{2}{|c|}{ SA } & \multicolumn{2}{|c|}{ A } & \multicolumn{2}{|c|}{ D } & \multicolumn{2}{|c|}{ SD } & \multirow{2}{*}{ WM } & \multirow{2}{*}{ DV } \\
\hline & $\mathrm{F}$ & WV & $\mathrm{F}$ & WV & $\mathrm{F}$ & WV & $\mathrm{F}$ & WV & & \\
\hline 1. I really care about the future of UB. & 47 & 188 & 15 & 45 & 1 & 2 & 0 & 0 & 3.73 & SA \\
\hline $\begin{array}{l}\text { 2. I am proud to work for my school/ } \\
\text { university. }\end{array}$ & 48 & 192 & 14 & 42 & 0 & 0 & 1 & 1 & 3.73 & SA \\
\hline $\begin{array}{l}\text { 3. I have sense of personal } \\
\text { accomplishment from my job. }\end{array}$ & 41 & 164 & 20 & 60 & 2 & 4 & 0 & 0 & 3.62 & SA \\
\hline 4. UB is a good place to work. & 34 & 136 & 28 & 84 & 1 & 2 & 0 & 0 & 3.52 & SA \\
\hline 5. UB inspires me to do my best work. & 31 & 124 & 30 & 90 & 1 & 2 & 1 & 1 & 3.44 & SA \\
\hline $\begin{array}{l}\text { 6. I understand how my department } \\
\text { contributes to UB's success. }\end{array}$ & 45 & 180 & 17 & 51 & 1 & 2 & 0 & 0 & 3.70 & SA \\
\hline
\end{tabular}




\begin{tabular}{|l|l|l|l|l|l|l|l|l|l|l|}
\hline $\begin{array}{l}\text { 7. I understand how my role relates to } \\
\text { UB's goals and objectives. }\end{array}$ & 40 & 160 & 22 & 66 & 1 & 2 & 0 & 0 & 3.62 & SA \\
\hline $\begin{array}{l}\text { 8. I am personally motivated to help UB } \\
\text { succeed. }\end{array}$ & 30 & 120 & 29 & 87 & 2 & 4 & 2 & 2 & 3.38 & SA \\
\hline $\begin{array}{l}\text { 9. I am willing to put in a great deal } \\
\text { of effort beyond what is normally } \\
\text { expected. }\end{array}$ & 28 & 112 & 31 & 93 & 4 & 8 & 0 & 0 & 3.38 & SA \\
\hline $\begin{array}{l}\text { 10. I am satisfied with the way our school } \\
\text { rewards and recognizes those who do } \\
\text { their job well. }\end{array}$ & 18 & 72 & 35 & 105 & 10 & 20 & 0 & 0 & 3.13 & $\mathrm{~A}$ \\
\hline $\begin{array}{l}\text { 11. My personal vision and mission are } \\
\text { linked to UB's vision and mission. }\end{array}$ & 22 & 88 & 37 & 111 & 4 & 8 & 0 & 0 & 3.29 & $\mathrm{SA}$ \\
\hline $\begin{array}{l}\text { 12. While on the job, my ideas and } \\
\text { opinions are taken with respect. }\end{array}$ & 22 & 88 & 34 & 102 & 7 & 14 & 0 & 0 & 3.24 & $\mathrm{~A}$ \\
\hline $\begin{array}{l}\text { 13. I feel that senior management is } \\
\text { concerned about my welfare. }\end{array}$ & 13 & 52 & 38 & 114 & 12 & 24 & 0 & 0 & 3.02 & $\mathrm{~A}$ \\
\hline 14. I work with responsible persons. & 27 & 108 & 32 & 96 & 4 & 8 & 0 & 0 & 3.37 & $\mathrm{SA}$ \\
\hline Composite mean & & & & & & & & 3.44 & $\mathrm{SA}$ \\
\hline
\end{tabular}

Legend:

$\begin{array}{rrllll}3.25-4.0 & \text { SA } & \text { Strongly Agree } & 1-1.74 & \text { SD } & \text { Strongly Disagree } \\ 2.50-3.2 & \text { A } & \text { Agree } & 1.75-2.49 & \text { D } & \text { Disagree }\end{array}$

Table 1 shows the defining engagement of the respondents. Eleven (11) items were rated Strongly Agree, these items are as follows: item $1-1$ really care about the future of UB, 3.73, item 2-I am proud to work for my school/university, 3.73; item 6-I understand how my department contributes to UB's success, 3.70; item 3-I have a sense of personal accomplishment from my job, 3.62, item 7-I understand how my role relates to UB's goals and objectives, 3.62; item 4-UB is a good place to work, 3.52; item 5-UB inspires me to do my best work, 3.44; items 8 \& 9-I am personally motivated to help UB succeed, and I am willing to put in a great deal of effort beyond what is normally expected, 3.38; item 14-I work with responsible persons, 3.37; and item 11-My personal vision and mission are linked to UB's vision and mission, 3.29.

Three items were rated Agree by the respondents, these were the following:

Item 12-While on my job, my ideas and opinions are taken with respect, 3.24; item10-I am satisfied with the way our school rewards and recognizes those who do their job well, 3.13, item 13-I feel that senior management is concerned about my welfare, 3.02 . 
The composite mean was 3.44, Strongly Agree, which means that the nonteaching employees were highly engaged/committed to their work/job. These findings validate that the UB employees have the defining engagement as their job and personal resources claimed by Bakker 2008 in his findings that work engagement includes vigor, dedication and absorption.

Table 2. Driving Engagement

$\mathrm{N}=63$

\begin{tabular}{|c|c|c|c|c|c|c|c|c|c|c|}
\hline \multirow{2}{*}{ DRIVING ENGAGEMENT } & \multicolumn{2}{|c|}{ SA } & \multicolumn{2}{|r|}{ A } & \multicolumn{2}{|c|}{ D } & \multicolumn{2}{|c|}{ SD } & \multirow{2}{*}{ WM } & \multirow{2}{*}{ DV } \\
\hline & $\mathrm{F}$ & WV & $\mathrm{F}$ & WV & $F$ & WV & $\mathrm{F}$ & WV & & \\
\hline $\begin{array}{l}\text { 1. Senior management always thinks of } \\
\text { putting first my well-being. }\end{array}$ & 13 & 52 & 41 & 123 & 9 & 18 & 0 & 0 & 3.06 & A \\
\hline $\begin{array}{l}\text { 2. UB provides challenging, creative and } \\
\text { varied work that utilizes my old and new skills. }\end{array}$ & 15 & 60 & 44 & 132 & 4 & 8 & 0 & 0 & 3.17 & A \\
\hline $\begin{array}{l}\text { 3. Senior management involved us } \\
\text { (employees) in making important decisions for } \\
\text { the good of the university. }\end{array}$ & 20 & 80 & 32 & 96 & 9 & 18 & 2 & 2 & 3.11 & A \\
\hline $\begin{array}{l}\text { 4. UB cares a great deal about customer } \\
\text { satisfaction. }\end{array}$ & 18 & 72 & 37 & 111 & 7 & 14 & 1 & 1 & 3.14 & A \\
\hline $\begin{array}{l}\text { 5. My pay system is competitive compared to } \\
\text { similar jobs in other institutions. }\end{array}$ & 13 & 52 & 37 & 111 & 10 & 20 & 3 & 3 & 2.95 & A \\
\hline 6. UB has a reputation as a good employer. & 20 & 80 & 40 & 120 & 3 & 6 & 0 & 0 & 3.27 & SA \\
\hline $\begin{array}{l}\text { 7. I feel comfortable collaborating with co- } \\
\text { employees. }\end{array}$ & 21 & 84 & 40 & 120 & 2 & 4 & 0 & 0 & 3.30 & SA \\
\hline $\begin{array}{l}\text { 8. UB provides sufficient incentive for us } \\
\text { (employees) to perform well. }\end{array}$ & 21 & 84 & 32 & 96 & 8 & 16 & 2 & 2 & 3.14 & A \\
\hline $\begin{array}{l}\text { 9. Everyone is treated with respect at work, } \\
\text { regardless of who we are. }\end{array}$ & 17 & 68 & 38 & 114 & 5 & 10 & 3 & 3 & 3.10 & A \\
\hline $\begin{array}{l}\text { 10. The materials, tools and equipment that I } \\
\text { need to do my job are supplied by the school } \\
\text { and made readily available to me. }\end{array}$ & 16 & 64 & 34 & 102 & 10 & 20 & 3 & 3 & 3.00 & A \\
\hline $\begin{array}{l}\text { 11. UB allows me to maintain a reasonable } \\
\text { balance between my family and work life. }\end{array}$ & 19 & 76 & 38 & 114 & 6 & 12 & 0 & 0 & 3.21 & A \\
\hline $\begin{array}{l}\text { 12. Senior management appreciate/value } \\
\text { employees. }\end{array}$ & 14 & 56 & 43 & 129 & 6 & 12 & 0 & 0 & 3.13 & A \\
\hline $\begin{array}{l}\text { 13. The administration gives assistance/ } \\
\text { support to my personal concerns. }\end{array}$ & 13 & 52 & 40 & 120 & 10 & 20 & 0 & 0 & 3.05 & A \\
\hline $\begin{array}{l}\text { 14. The administration gives assistance/ } \\
\text { support to my professional and work related } \\
\text { activities. }\end{array}$ & 14 & 56 & 41 & 123 & 8 & 16 & 0 & 0 & 3.10 & A \\
\hline $\begin{array}{l}\text { 15. The management provides equal } \\
\text { opportunities for, and access to, career } \\
\text { growth, development and training } \\
\text { opportunities. }\end{array}$ & 15 & 60 & 37 & 111 & 10 & 20 & 1 & 1 & 3.05 & A \\
\hline Composite Mean & & & & & & & & & 3.12 & A \\
\hline Overall Composite mean & & & & & & & & & 3.28 & SA \\
\hline
\end{tabular}


Table 2 illustrates the diving engagement of the respondents. Of the fifteen items enumerated, only two got a rating of Strongly Agree. The highest rated item which received a mean weight of 3.30 was item 7 , I feel comfortable collaborating with co-employees; and second in rank was item 6, UB has a reputation as a good employer, 3.27.

The rest of the items were rated Agree. These were: item 11, UB allows me to maintain a reasonable balance between my family and work life, 3.21 ; item 2, UB provides challenging, creative and varied work that utilizes my old and new skills, 3.17; items 4 \& 8, UB cares a great deal about customer satisfaction, and UB provides sufficient incentive for us(employees) to perform well, 3.14; item 12, Senior management appreciates/values employees, 3.13; item 3, Senior management involves us (employees) in making important decisions for the good of the university, 3.11; items $9 \& 14$, Everyone is treated with respect at work, regardless of who we are, and The administration gives assistance/support to my professional and work related activities, 3.10; item 1, Senior management always think of putting first my well-being, 3.06; ranked 12.5, items 13 and 15, The administration gives assistance/support to my personal concerns, and The management provides equal opportunities for, and access to, career growth, development and training opportunities, 3.05; item 10, The materials, tools and equipment that I need to do my job are supplied by the school and made readily available to me, 3.00; and item 5, My pay system is competitive compared to similar jobs in other institutions, 2.95.

The composite mean was 3.12, Agree or they were motivated/driven in their work. The overall composite mean of the perceived level of engagement in terms of defining and driving engagement was rated Strongly Agree or the tenured non-teaching employees were motivated/highly engaged in their work.

During the focus group discussion, salient concerns were raised on communication and giving of feedback, the tenured non-teaching employees suggested that the institution should provide regular one-on-one updates, detailed information dissemination especially how an employee was ranked and rated. It was also observed that they were given less responsibilities/involvement to organize institutional activities or programs.

The findings of this study are consistent with those of Perrin (2008) who found out that while there are several employees who are more than willing to contribute more at work, the actions of their administrators and managers along with the culture of their organizations and human resource practices can play a major role on employees' engagement. 


\section{CONCLUSION}

The highly engaged/motivated rating on the level of engagement as perceived by the tenured non-teaching employees is an indicator that the institution provides the basic workplace needs. However, it is a challenge to the institution and the human resource office to seek for the right knowledge, new strategies, new incentives and expertise that can enhance employee work engagement.

The human resource program of the institution should focus on strategies to keep employees engaged in their job and improve positive organizational performance. The strategies should include the following: enhancing employeremployee relationship through responsible communication and feedback, recognizing the effort and results of the employees' contribution be it inside or outside the institution, providing a working environment where workers will be stimulated, be given authority and autonomy, and providing access to information and resources as well as growth and development opportunities.

Employers who build proactive leadership, respect, listen and recognize each worker as a catalyst of change will produce fully engaged employees.

\section{LITERATURE CITED}

Bakker, A. B., \& Demerouti, E. (2008). Towards a model of work engagement. Career development international, 13(3), 209-223. Retrieved from http://goo.gl/jHI3ON (Accessed last April 10, 2014).

Mison, lone, Bernabe, L., Human Behavior in Organization. National Book Store, 2004.

Markos, S Sridevi M. (2010). Online employee engagement: the key to improving performance. International Journal of Business and Management Vol.5, No.12. Retrieved from www.ccsenet.org/ijbm (Accessed April 15, 2014).

Accord Management Systems (2009). Employee engagement strategy: a strategy to move from employee satisfaction to engagement. Retrieved from www.accordsyst.com/papers/engagement_wp.pdf.

Miller, S. L. (2008). An Employee Engagement Assessment of XYZ Manufacturing Company (Doctoral dissertation, University of Wisconsin-Stout). Retrieved from http://goo.gl/rJDgUa (Accessed last April 15, 2014). 
Perrin T. (2008). Online working today: understanding what drives employee engagement, the 2003 Towers Perin Talent Report U.S. Report. Retrieved from http://goo.gl/NnkUH5 (Accessed last April 15, 2014).

Robbins, S. P., Judge, T. A. Organizational Behavior. Singapore: Prentice Hall, 2011.

Kinicki, A. Williams, B. Management: A Practical Introduction. The McGraw-Hill Companies, Inc. New York, 2009.

Settoon, R., Bennett, N., Liden, R. (1996). Social exchange in organizations: perceived organizational support, leader-member exchange, and employee reciprocity. Journal of Applied Psychology Vol.81.No.3. 219227 Retrieved from http://goo.gl/UqGDI4 (Accessed last April 14, 2014).

Wayne, S. J., Shore, L. M., \& Liden, R. C. (1997). Perceived organizational support and leader-member exchange: A social exchange perspective. Academy of Management journal, 40(1), 82-111. Retrieved from http://goo.gl/ TaEouw (Accessed last April 15, 2014).

White, B., (2013). Employee engagement research update, January 1, 2013. Retrieved from http://goo.gl/XUq9ZA (Accessed last April 10, 2014). 